Article

ULGUIM, A.R. ${ }^{*}$

FRANCO, J.J. ${ }^{2}$

SILVA, J.D.G. ${ }^{3}$

AGOSTINETTO, D. ${ }^{3}$

VARGAS, L. ${ }^{4}$

\section{Evaluation of The Mechanism Responsible FOR THE LOW-LEVEL RESistance TO GLYPHOSATE IN GoOSEgRASS}

\author{
Avaliação do Mecanismo Responsável pela Resistência de Nível Baixo ao \\ Glyphosate em Capim-Pé-de-Galinha
}

\begin{abstract}
Goosegrass (Eleusine indica) infests various crops, being reported as low-level resistant (LLR) to glyphosate. The objectives of this study were to evaluate the mechanisms of resistance to glyphosate in goosegrass by the cyt-P450 complex to identify changes in leaf anatomy of these plants and quantify the accumulation of shikimate in biotypes susceptible and with LLR. The metabolic rate was assessed by applying the cyt-P450 malathion inhibitor 30 minutes before the herbicide application. The analysis of the leaf anatomy consisted of a characterization of anatomic cross-sections and evaluation of the effect of glyphosate on the leaf epidermis and the conducting vessels. Plant tissue was collected 24 hours after treatment (HAT) of the dose-response curve to evaluate the accumulation of shikimate. The LLR biotype has not shown glyphosate metabolism by the early application of malathion due to the control of about $65 \%$ with or without applying the inhibitor. There is no anatomical evidence to determine the differential absorption of glyphosate by LLR biotypes. However, there is evidence of lower absorption and translocation of glyphosate in this biotype by lower stomatal density and a smaller diameter of the phloem. However, the LLR biotype presents diameter of phloem of $0.027 \mathrm{~mm}$ and stomatal density of $91.23 \mathrm{~mm}^{-2}$, values which are below the observed ones on the susceptible biotype. The susceptible biotype presents shikimate accumulation $17 \%$ higher compared to the biotype with LLR at a dose of $1,080 \mathrm{~g}$ e.a. ha ${ }^{-1}$, allowing to infer that the resistance mechanism is related to the enzyme insensitivity to the herbicide, which enables the use of appropriate management practices to control this weed.
\end{abstract}

Keywords: cyt-P450 monooxygenase, shikimate, absorption and translocation, EPSPs, Eleusine indica.

RESUMO - O capim-pé-de-galinha (Eleusine indica) é infestante de diversos cultivos, sendo relatado como resistente de nível baixo (RNB) ao herbicida glyphosate. Os objetivos deste trabalho foram avaliar mecanismos de resistência de capim-pé-degalinha ao glyphosate, por meio de metabolização do herbicida pelo complexo cyt-P450, alterações na anatomia foliar e acúmulo de chiquimato nos biótipos suscetivel e com RNB. A metabolização foi avaliada mediante a aplicação do inibidor de cyt-P450 malathion 30 min antes do herbicida. A análise da anatomia foliar constou da caracterização de cortes anatômicos e avaliação do efeito do glyphosate na epiderme foliar e nos vasos condutores. Para avaliar o acúmulo de chiquimato, foi coletado tecido vegetal 24 horas após tratamento (HAT) da curva de dose-resposta. O biótipo RNB não evidenciou metabolismo do glyphosate pela aplicação prévia de malathion, não diferindo do tratamento somente com o herbicida. Não existem evidências anatômicas que determinem a absorção

Planta Daninha 2017; v35:e017161140

1 Instituto Rio Grandense do Arroz, Cachoeirinha, Rio Grande do Sul, Brasil; ${ }^{2}$ Schroder Consultoria, Pelotas, RS, Brasil;

${ }^{3}$ Universidade Federal de Pelotas, Pelotas, RS, Brasil; ${ }^{4}$ Empresa Brasileira de Pesquisa Agropecuária, Embrapa Trigo, Passo Fundo, RS, Brasil. 
diferencial do herbicida glyphosate pelo biótipo RNB. Entretanto, o biótipo RNB apresentou diâmetro do floema de 0,027 mm e densidade de estômatos de 91,23 $\mathrm{mm}^{-2}$, valores inferiores aos observados no biótipo suscetivel, levando a indícios de menor absorção e translocação de glyphosate nesse biótipo. $O$ biótipo suscetivel apresentou acúmulo de chiquimato 17\% superior, comparado ao biótipo RNB, na dose de $1.080 \mathrm{~g}$ a.e. $\mathrm{ha}^{-1}$, permitindo inferir que o mecanismo de resistência seja relacionado à insensibilidade da enzima-alvo ao herbicida, o que possibilita o uso de práticas de manejo adequadas para o controle dessa planta daninha.

Palavras-chave: cyt-P450 mono-oxigenase, chiquimato, absorção e translocação, EPSPs, Eleusine indica .

\section{INTRODUCTION}

Goosegrass (Eleusine indica) infests several crops and may cause irreversible damage on yield, specially when competing in the initial stages of the crops (Benedetti et al., 2009). Worldwide, this weed has 29 cases of resistance belonging to seven mechanisms of action, with 11 cases of resistance to glyphosate being reported. In Brazil, this species is reported as having endurance to acetyl-coenzyme A carboxylase (ACCase) inhibitors (Vidal et al., 2006).

The resistance refers to the biotype inherent and inheritable ability to survive and reproduce after exposure to the recommended dose of herbicide that is normally lethal to susceptible populations of the same species. Scientific resistance or low-level resistance (LLR) is characterized by a difference in control among populations when using underdoses, but it shows a satisfactory control in the recommended dose (Gazziero et al., 2014). LLR was observed in a biotype of goosegrass originating from Brazilian city Boa Vista do Incra, RS, when using up to $1,080 \mathrm{~g}$ of acid equivalent (a.e.) ha ${ }^{-1}$ of glyphosate, showing a resistance factor of 1.17 (Vargas et al., 2013).

The mechanism by which the weeds resist to herbicides is important and determines the level in which this resistance is expressed in the field (Powles and Yu, 2010). Thus, it is essential to know it in the characterization of resistance. The resistance mechanisms may result from changes in the herbicide target sites (target site resistance), as in the case of populations of Eleusine indica resisting to glyphosate due to the replacement of amino acids in positions 102 and 106 of 5-enolpyruvylshikimate-3-phosphate synthase (EPSPs) (Yu et al., 2015) or by changes that do not occur in the site of action (non-target site resistance) (Powles and Yu, 2010). This latter resistance mechanism may involve the reduction of the uptake and translocation of the herbicide, as for Conyza bonariensis (Dinelli et al., 2008) resisting to glyphosate, compartmentalization of glyphosate in the vacuole in C. canadensis (Ge et al., 2009) or even the metabolism action such as resistance of Lolium rigidum to acetolactate synthase (ALS) and ACCase inhibitors (Yu et al., 2009).

The metabolism action of herbicides can occur by the action of the cyt-P450 monooxygenase complex or glutathione S-transferase, whose resistant plants acquire the ability to detoxify the herbicide more rapidly than the sensitive ones (Roso and Vidal, 2010). Resistant biotypes of Echinochloa crusgalli have demonstrated, as a resistance mechanism to inhibitors of ALS, metabolism action via P450 (Riar et al., 2012). In a resistant biotype of Digitaria insularis, metabolism action of herbicide glyphosate was observed and to this characteristic is attributed the contribution to the resistance mechanism of the species (Carvalho et al., 2012).

The characteristics of surface and leaf anatomy may affect the effectiveness of glyphosate absorption by weeds (Huangfu et al., 2009). Features such as composition of the cuticle, angle and position of the leaf and number of stomata, trichomes and glands interfere with the foliar absorption of herbicides (Malpassi, 2006) and may indicate auxiliary resistance mechanisms. Some anatomical features observed in species of Amaranthus deflexus, A. spinosus, Alteranthera tenella and Euphorbia heterophylla can be foliar barriers to herbicide penetration (Ferreira et al., 2003). Thus, weeds anatomy characteristics may influence resistance to herbicides and their determination is important.

Another strategy to evaluate the resistance mechanism to glyphosate involves determining shikimate levels, constituting a fast and efficient alternative (Nol et al., 2012). The application 
of glyphosate causes shikimate accumulation in plant tissues and this accumulation is higher in susceptible biotypes compared to resistant biotypes of the same species. In a susceptible biotype of Conyza sumatresis, an increase of $620 \%$ of shikimate was observed, compared to the biotype resistant to glyphosate (Gonzáles-Torralva et al., 2014), indicating insensitivity of the target enzyme.

Most of the cases of resistance of Eleusine indica to herbicides is due to change of the site of action (Heap, 2016). Thus, knowledge of the mechanism by which goosegrass plants present LLR to glyphosate is important and can determine control measures to slow down to the maximum the progress towards a possible case of resistance. This work has had as hypotheses the fact that LLR is caused by changes in the enzyme due to low RF and there may be changes in leaf anatomy that favor the emergence of LLR. Therefore, the objectives of this study were to evaluate the metabolism action of glyphosate by cyt-P450 complex, identify changes in leaf anatomy of these plants that may suggest change in herbicide absorption and quantify the shikimate accumulation in goosegrass susceptible and LLR biotypes.

\section{MATERIALS AND METHODS}

Three studies were conducted between 2011 and 2013 in a greenhouse. The first and the third ones consisted of one experiment each, while the second one consisted of two experiments. The first study was related to the metabolism action of glyphosate by biotypes of goosegrass. The second one to the analysis of leaf anatomy. And the third one to the shikimate accumulation of these biotypes. Two biotypes were used, considered as having LLR (Boa Vista do Incra, RS, 28.940277 S and -53.411684 W) and another one, susceptible (Camaquã, RS, -30.839221 S and $51.862697 \mathrm{~W}$ ), determined in previous studies (Vargas et al., 2013).

The experiments were conducted in a completely randomized design with four, three and six replications for the experiments of the first, second and third studies, respectively. The experimental units consisted of pots with $0.5 \mathrm{~L}$ capacity, containing Red-Yellow Acrisol soil type. In the shikimate accumulation experiment, commercial substrate GerminaPlant ${ }^{\circledR}$ and soil at 1:1 ratio were used to fill the pots. In each pot, three seeds of goosegrass were seeded and later, when the plants had two leaves, thinning was carried out, leaving two (first and third experiments) or one plant per pot (second and fourth experiments).

\section{Metabolizing glyphosate}

The treatments were arranged in a factorial design, whose factor A tested the goosegrass LLR biotype and another biotype notoriously susceptible (Vargas et al., 2013). And factor B consisted in the application or not of malathion insecticide, an inhibitor of cyt-P450 monooxygenase. The application of the treatments was performed when the plants were in the recommended stage of control, from four leaves to one tiller. Thirty minutes prior to the application of glyphosate isopropylamine salt at a dose of $1,080 \mathrm{~g}$ a.e. ha ${ }^{-1}$ and without the addition of an adjuvant, malathion, an inhibitor of metabolism action at a dose of 1,000 $\mathrm{g}$ a.i. ha- ${ }^{-1}$, was applied (Yu et al., 2009). In both applications, a knapsack sprayer was used, pressurized at $\mathrm{CO}_{2}$, with AVI 110.015 fan-type spraying nozzle tips, which provided an application volume of $150 \mathrm{~L} \mathrm{ha}^{-1}$.

The variables analyzed were: control at 10, 20 and 30 days after the application (DAA) of the treatments and shoots dry matter (DM) at 30 DAA. The control evaluation was done using a percentage scale, where 0 represented no injury and 100 represented plant death (SBCPD, 1995). To determine the DM, the material collection and drying in a forced air circulation oven at $60{ }^{\circ} \mathrm{C}$ until constant weight were carried out, when the material was weighed and the value was transformed for the plant ${ }^{-1} \mathrm{DM}$.

\section{Leaf anatomy}

For characterization and anatomical assessment of the leaves of goosegrass biotypes, two experiments were conducted: the first one on the characterization of the leaf anatomy and the second one on the analysis of anatomical changes of biotypes by the application of glyphosate. 


\section{Anatomical characterization}

For anatomical characterization of goosegrass leaves, seeds of LLR and susceptible biotypes were cultured from the four-leaf stage to one tiller, when samples from the fourth leaf of plants were collected to perform the analyses. Samples of the leaves collected were fixed in Karnovsky fixative, modified using phosphate buffer solution $\mathrm{pH} 7.2$, dehydrated in an ascending ethanol series and infiltrated in plastic resin (Leica Historesin ${ }^{\circledR}$ ), according to the manufacturer's instructions.

The samples were transected in a manual rotary microtome (ANCAP) with a disposable razor $\left(\right.$ Feather $\left.^{\circledR}\right)$. The $5 \mu \mathrm{m}$ thick transections were stained with $0.05 \%$ toluidine blue in a phosphate buffer solution and $\mathrm{pH} 4.5$ citrate and mounted on Entellan ${ }^{\circledR}$ synthetic resin $\left(\mathrm{Merck}^{\mathbb{R}}\right)$. Documenting the results was performed by capturing images from the blades using a Leica ${ }^{\circledR}$ DC $300 \mathrm{~F}$ camera attached to the Leica ${ }^{\circledR}$ DM LB microscope.

\section{Anatomical changes due to the application of glyphosate}

The analysis experiment of anatomical changes was carried out in a three-factor arrangement, whose factor A tested the biotypes of goosegrass (LLR and susceptible). Factor B consisted of stages of application (plants with 4 leaves without tillers and 1 tillers). And factor $\mathrm{C}$ consisted of the application or not of glyphosate. Herbicide application was made as described above at a dose of 1,080 g a.e. ha ${ }^{-1}$ of glyphosate. The variables analyzed were stomatal density and stomatal index at 3 DAA and the phloem diameter, quantified in millimeters $(\mathrm{mm})$ at 7 DAA.

Stomatal density and stomatal index were evaluated by analyzing the epidermal surface of the last two fully developed leaves. In order to do this, leaf impressions were made by applying a fine colorless glaze layer, being removed with a transparent adhesive tape after drying and displayed on slides.

Portions of the middle area of the leaf blade were analyzed through microscopic analysis of two fields by sampled leaf, totaling six analytical repetitions in fields of an area corresponding to $0.4275 \mathrm{~mm}^{2}$ in the abaxial (Ab) and adaxial (Ad) epidermis. The stomatal density was converted into stomata $\mathrm{mm}^{-2}$, while the stomatal index was calculated using the equation proposed by Cutter (1986), as follows:

$$
S I=N S /(C E+N S) \times 100
$$

where $S I$ is the stomatal index, NS is the number of stomata and $C E$ is the number of epidermal cells. The leaf prints were observed and captured as mentioned above and the images were scanned and increased 20x.

Samples of leaves collected at 7 DAA were fixed, dehydrated, sectioned and stained as previously mentioned. Documenting the results was performed as previously described and captures of six portions of the cuts belonging to two and one blades were held for the treatments that received or not, respectively, the herbicide application. The measurements were performed with the aid of the software Image ${ }^{\circledR}$, wherein the phloem diameters were measured in $\mathrm{mm}$, in parallel in relation to the leaf epidermis.

\section{Accumulation of shikimate}

Determination of shikimate accumulation of biotypes of goosegrass was held in a factorial arrangement whose factor A tested the biotypes of goosegrass (LLR and susceptible). And factor B consisted of the application of growing doses of glyphosate $(0,90,180,360,720,1,440,2,880$, $5,760,11,520 \mathrm{~g}$ a.e. $\left.\mathrm{ha}^{-1}\right)$. The application took place as described above, except for volume of application, and $120 \mathrm{~L} \mathrm{ha}^{-1}$ were used in this work.

The extraction of shikimate was performed according to modifications by Perez-Jones et al. (2007). The leaf tissue used in the extraction of shikimate came from the fourth fully expanded leaf, collected 24 hours after application (HAT) and the interval between the application of glyphosate and the collection of the material was determined in a preliminary experiment (data not shown). The leaf tissues corresponding to $0.05 \mathrm{~g}$ of leaf mass of each biotype were inserted 
into a microtube containing $1 \mathrm{~mL}$ of $\mathrm{HCl}(1.25 \mathrm{~N})$. Samples were shaken, stored at $-20{ }^{\circ} \mathrm{C}$ until freezing and submitted to a water bath for $45 \mathrm{~min}$ at $37{ }^{\circ} \mathrm{C}$. Two aliquots of $125 \mu \mathrm{L}$ per sample were mixed with $1 \mathrm{~mL}$ of reaction buffer [periodic acid $0.25 \%(\mathrm{~m} / \mathrm{v}) /$ sodium metaperiodate $0.25(\mathrm{~m} / \mathrm{v})]$ and submitted to a water bath for $30 \mathrm{~min}$ at $37^{\circ} \mathrm{C} .1,000 \mu \mathrm{L}$ of buffer $(0.6 \mathrm{~N} \mathrm{NaOH} /$ $0.22 \mathrm{M} \mathrm{Na}_{2} \mathrm{SO}_{3}$ ) were added to this solution. The shikimate accumulation was measured by a spectrophotometer (Ultrospec2000 UV/Visivel - Pharmacia Biotech) in wave length of $380 \mathrm{~nm}$. The concentration of shikimate expressed in $\mathrm{mg} \mathrm{mL}^{-1}$ of solution was determined in a standard curve.

\section{Statistical analysis}

The data from each study were submitted to an analysis of variance $(p \leq 0.05)$. Upon found statistically significant, specific procedures were performed.

\section{Metabolizing glyphosate}

The comparison among the means was done by the analysis of variance ( $\mathrm{F}$ test) $(\mathrm{p} \leq 0.05)$ itself in view of the levels of the treatment factors. When an interaction among the factors studied was observed, there was a new analysis of variance (F test), isolating each treatment factor.

\section{Leaf anatomy}

For the data on leaf anatomy, qualitative assessments were made while for the characterization and anatomical changes, when significance was observed for the main effect of each treatment factor or interaction among the factors tested. The result of the analysis of variance $(F$ test) $(\mathrm{p} \leq 0.05)$ was used as the criterion for distinguishing the means, as described above.

\section{Accumulation of shikimate}

As for the shikimate accumulation experiment, regression analysis was carried out for the doses of glyphosate factor and for the biotype factor, proceeding to a comparison of $\mathrm{I}_{50}$, which is the dose required to achieve 50\% of shikimate accumulation response (Seefeldt et al., 1995). For the regression analysis, the data were adjusted to the sigmoidal regression equation (Seefeldt et al., 1995):

$$
y=a /(1+\exp (-(x-x O) / b))
$$

where: $y=$ accumulation of shikimate $\left(\mathrm{mg} \mathrm{mL}^{-1}\right) ; x=$ dose of the herbicide (g a.e. ha ${ }^{-1}$ ); $a=$ difference between the maximum and minimum limits of the curve; $x O=$ represents the amount necessary to promote $50 \%$ of the $y$ axis response estimated by the model; and $b=$ angle of the curve.

The values of $I_{50}$ were obtained by arithmetical calculation based on estimated values in the equation coefficients. From the values of $I_{50}$ the resistance factor (RF) was obtained for the biotype with LLR compared to the susceptible one. To use the RF it was necessary to check the confidence interval ( $\mathrm{p} \geq 0.95)$. The overlap of the confidence interval of the susceptible biotype compared to the one with LLR indicates no difference in shikimate accumulation among biotypes.

\section{RESULTS AND DISCUSSION}

\section{Metabolizing glyphosate}

In the metabolizing experiment, there was an interaction among the factors studied at 10 DAA (Table 1). There was no statistical significance for the remaining evaluation periods and variable DM (data not shown). Failure to observe differences for the other variables stems from the fact that the biotype has a LLR, whose dose necessary to control $50 \%$ of the population $\left(\mathrm{DL}_{50}\right)$ ranged from 335 to 453 g a.e. ha-1 (Vargas et al., 2013). Therefore, the hypothesis that the 
Table 1 - Control (\%) of biotypes of goosegrass (Eleusine indica) after application of glyphosate $\left(1,080 \mathrm{~g}\right.$ a.e. $\left.\mathrm{ha}^{-1}\right)$ with previous application of the inhibitor of cyt-P450 monooxygenase malathion $\left(1,000 \mathrm{~g}\right.$ a.i. ha $\left.{ }^{-1}\right)$ at 10 days after the application (DAA) of the treatments

\begin{tabular}{|l|c|c|}
\hline \multirow{2}{*}{\multicolumn{2}{|c|}{ Biotype }} & \multicolumn{2}{c|}{ Malathion } \\
\cline { 2 - 3 } & With & Without \\
\hline LLR & 68 a A & 65 b A \\
\hline Susceptible & 71 a B & 93 a A \\
\hline VC $^{(1)}(\%)$ & \multicolumn{2}{|c|}{8.92} \\
\hline
\end{tabular}

Means followed by the same lowercase letter in the column comparing biotypes for applying malathion or not and uppercase letter in the row comparing the application of malathion for each biotype do not differ significantly by the F-test (analysis of variance) $(\mathrm{p} \leq 0.05)$. ${ }^{(1)}$ Variation coefficient. action of the herbicide with the action of P450 complex (Yu et al., 2009). Also for Digitaria insularis, glyphosate was degraded into aminomethylphosphonic acid (AMPA), glyoxylate, and sarcosine in the resistant biotype, whereas the susceptible biotype showed little glyphosate degradation potential, and this mechanism may contribute to the species resistance (Carvalho et al., 2012).

Cyt-P450 is a large family of monooxygenase genes that plays an important role in the metabolism of various substances, acting in the oxidation of xenobiotics and promoting the detoxification of the organism (Zhu et al., 2008). The inhibition of cyt-P450 complex by applying malathion and amitrole has shown multiple resistance to chlorsulfuron and diclofop, respectively, in a biotype of Lolium rigidum related to metabolizing herbicides (Yu et al., 2009). Inhibitor 1aminobenzotriazole has also indicated the metabolism of herbicide chlortuluron via cyt-P450, providing the resistance of Bromus tectorum to the herbicide (Menendez et al., 2006). It should be noted that no cases of resistance to glyphosate by action of this enzyme complex were detected.

\section{Leaf anatomy}

For the study of leaf anatomy, the analyses relating to the descriptive anatomical assessments of goosegrass leaf have not allowed to identify changes that could characterize a differential absorption of glyphosate among biotypes (Figure 1).

The leaf anatomy of goosegrass shows uniseriate epidermis on both sides of the blade (Figure 1). The stomata are both on the adaxial epidermis and the abaxial epidermis, featuring the leaf as amphistomatic. The presence of bulliform cells is characteristic of the species, both in the midrib and in the portion between the midrib and the edge of the blade. Also, the presence of sclerenchyma in the adaxial and abaxial portions of the vascular bundles was noticed.

Although anatomical differences were not found in biotypes of goosegrass, quantitative studies or analyses by an electron microscope could provide better information to infer the absorption and translocation of glyphosate. The biotype of Lolium multiflorum resistant to glyphosate has shown less compacted mesophyll cells as well as a minor ratio of phloem in relation to xylem when compared to the susceptible one (Galvan et al., 2012).

For the epidermis anatomical analysis of goosegrass leaves at 3 DAA there was no triple interaction among the factors studied for any variable. However, there was an interaction between growth stage and application of glyphosate for the variables stomatal density and stomatal index on the adaxial surface of the leaves (Table 2) and main effect for stomatal density of the biotype factor (Table 3).

There was a lower stomatal index and stomatal density when applying the herbicide in the four-leaf stage, highlighting the harmful effects of glyphosate on the leaf surface shortly after application, unlike what was observed at the absence of the application (Table 2). However, the non-observation of this situation for the 1-2-tiller stage corroborates the low glyphosate efficiency 

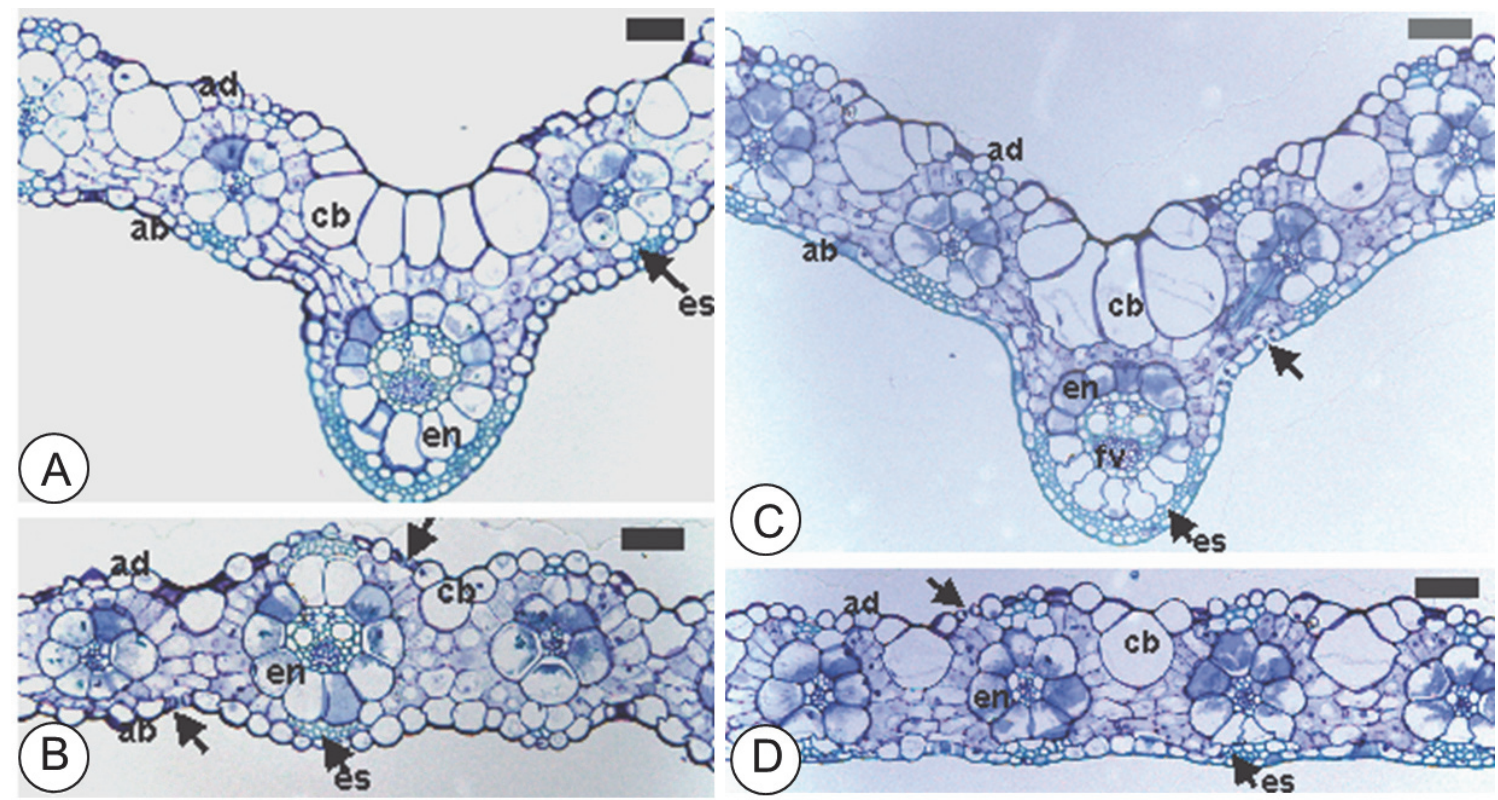

Arrow $=$ uniseriate epidermis with the presence of stomata; $\mathrm{ab}=$ adaxial epidermis; $\mathrm{cb}=$ bulliform cells; en = endoderm; es $=$ sclerenchyma; $\mathrm{fv}=$ vascular bundle; bars $=50 \mu \mathrm{m}$

Figure 1 - Cross-sections of the leaf blade of goosegrass (Eleusine indica) showing the midrib and the area between the midrib and the biotype blade with low-level resistance (LLR) (A and B) and susceptible biotype (C and D).

on goosegrass by herbicide application in advanced stages of development (Ulguim et al., 2013). The control of Conyza canadensis resistant to glyphosate was greater than $80 \%$ when the herbicide was applied in $10 \mathrm{~cm}$ high plants, whereas when the plants were treated with the herbicide at $15-20 \mathrm{~cm}$ height, the control did not reach 50\% (Vangessel et al., 2009).

Goosegrass plants with lower response to the application of quizalofop in an advanced growth stage have more epicuticular waxes when they have two or more tillers and thicker cuticle (Malpassi, 2006). The reduction of the cuticle thickness may be advantageous for the penetration of glyphosate and thus can lead to increased uptake of the herbicide (Huangfu et al., 2009).

In this study, it was observed that the biotype with LLR had less stomatal density than the susceptible biotype (Table 3). This feature can provide lower efficiency of the herbicide, since the cuticle on the guard cells seems to be thinner and more permeable (lower epicuticular wax content) than on other epidermal cells (Hess and Falk, 1990). With respect to that, it is important to note that the non-observation of interaction of this factor with the others indicates that it can not be considered a major feature in the biotype of LLR and further studies should be performed
Table 2 - Stomatal index and stomatal density of the adaxial side of goosegrass (Eleusine indica) leaves collected after three days of application (DAA) of glyphosate

\begin{tabular}{|l|c|c|}
\hline \multicolumn{1}{|c|}{$\begin{array}{c}\text { Stage of } \\
\text { application }\end{array}$} & With glyphosate & Without glyphosate \\
\hline \multicolumn{3}{|c|}{ Stomatal index } \\
\hline 4 leaves & $18.80 \mathrm{~b} \mathrm{~B}$ & 23.74 a A \\
\hline $1-2$ tillers & 21.72 a A & 22.86 a A \\
\hline VC (\%) & \multicolumn{3}{|c|}{12.83} \\
\hline \multicolumn{3}{|c|}{ Stomatal density mm ${ }^{-2}$} \\
\hline 4 leaves & 79.92 b B & 115.50 a A \\
\hline $1-2$ tillers & 105.46 a A & 107.99 a A \\
\hline VC $^{(1)}(\%)$ & & 19.78 \\
\hline
\end{tabular}

Lowercase letter in the column comparing the development stage for application or not of the herbicide and uppercase letter in the row comparing the application of glyphosate for each development stage do not differ significantly by the F-test (analysis of variance) $(\mathrm{p} \leq 0.05)$. (1) Variation coefficient.

Table 3 - Stomatal density of the adaxial side of leaves of biotypes of goosegrass (Eleusine indica) with low-level resistance (LLR) or susceptible collected three days after the application (DAA) or not of herbicide glyphosate

\begin{tabular}{|l|c|}
\hline \multicolumn{1}{|c|}{ Biotype } & Stomatal density $\mathrm{mm}^{-2}$ \\
\hline LLR & $91.23 \mathrm{~b}$ \\
\hline Susceptible & $111.21 \mathrm{a}$ \\
\hline $\mathrm{VC}^{(1)}(\%)$ & 21.52 \\
\hline
\end{tabular}

Means followed by the same letter in the column dot not show a significant difference by the F test (analysis of variance) $(\mathrm{p} \leq 0.05)$.

(1) Variation coefficient. 
to confirm the influence of stomatal density in the absorption of glyphosate.

Glyphosate moves in the phloem following the route of the products of photosynthesis, of the photosynthetically active leaves towards the growing parts (Roman et al., 2007). Anatomical changes that affect these parameters can lead to lower translocation of the herbicide in the plants. There was no interaction between the factors studied for the phloem diameter, but it was found that the application of glyphosate promoted reduction in this variable for the susceptible biotype, and no difference was observed for the biotype with LLR (Table 4). Larger phloem diameter for the susceptible biotype was observed when compared to the LLR when glyphosate was not applied, while there was no difference with the herbicide.

The susceptible biotype presented greater phloem diameter than the LLR biotype at 1-2 tiller stage, and this value was higher than the 4 leaf stage of the same biotype (Table 4). The fact that the LLR biotype has not shown an increase in phloem diameter may represent greater ability to tolerate the herbicide application, especially in the 1-2 tiller stage. It should be noted that the application of glyphosate in that biotype at that stage provided $74 \%$ control (Ulguim et al., 2013). Other studies should be conducted to confirm this characteristic, especially those involving the application of glyphosate radioisotopes and evaluation of its translocation. The biotype of Lolium multiflorum resistant to glyphosate showed lower herbicide translocation capacity in relation to the susceptible one, and a higher concentration of the herbicide was observed in the sensitive biotype in shoots and roots, while in the resistant one the higher amount of the product was in the leaf applied, and this feature may be responsible for resistance to glyphosate (Ferreira et al., 2006).

\section{Accumulation of shikimate}

There was an interaction between biotypes and glyphosate doses for the variable accumulation of shikimate, with an adjustment of the data to the sigmoidal regression equation. From the equations, the values of $I_{50}$ were calculated for the goosegrass susceptible and LLR biotypes.

Considering the dose used for weed management in postemergence soybean, equivalent to $1,080 \mathrm{~g}$ a.e. ha-1, it was noted that the shikimate accumulation in the goosegrass susceptible biotype was $2.47 \mathrm{mg} \mathrm{mL}^{-1}$, representing $17 \%$ increase compared to the biotype with LLR, which presented an accumulation of $2.12 \mathrm{mg} \mathrm{mL}^{-1}$ (Figure 2). The susceptible biotype of Ambrosia trifida accumulated $330 \%$ more shikimate than the resistant biotype when applying 840 g a.e. ha ${ }^{-1}$ (Norsworthy et al., 2010).

The glyphosate doses necessary to accumulate $50 \%$ of shikimate $\left(\mathrm{I}_{50}\right)$ were $72 \mathrm{~g}$ and $289 \mathrm{~g}$ a.e. $\mathrm{ha}^{-1}$ for the susceptible

Table 4 - Diameter of the phloem (mm) of leaves of biotypes of goosegrass (Eleusine indica) with low-level resistance

(LLR) or susceptible seven days after the application (DAA) of glyphosate in different application stages

\begin{tabular}{|l|c|c|}
\hline \multirow{2}{*}{ Biotype } & \multicolumn{2}{|c|}{ Application of glyphosate } \\
\cline { 2 - 3 } & With herbicide & Without herbicide \\
\hline LLR & $0.025773 \mathrm{a} \mathrm{A}$ & $0.027000 \mathrm{~b}$ A \\
\hline Susceptible & $0.027091 \mathrm{a} \mathrm{B}$ & $0.031222 \mathrm{a} \mathrm{A}$ \\
\hline \multirow{2}{*}{ Biotype } & \multicolumn{2}{|c|}{ Stage of application } \\
\cline { 2 - 3 } & 4 leaves & $1-2$ tillers \\
\hline LLR & $0.026444 \mathrm{a} \mathrm{A}$ & $0.026056 \mathrm{~b} \mathrm{~A}$ \\
\hline Susceptible & $0.027500 \mathrm{a} \mathrm{B}$ & $0.030722 \mathrm{a} \mathrm{A}$ \\
\hline VC $^{(1)}(\%)$ & & \\
\hline
\end{tabular}

Means followed by the same lowercase letter in the column comparing biotypes for applying or not the herbicide or application stages and uppercase letter in the row comparing application stages of glyphosate for each biotype do not differ significantly by the $\mathrm{F}$ test (analysis of variance) $(\mathrm{p} \leq 0.05)$. (1) Variation coefficient.

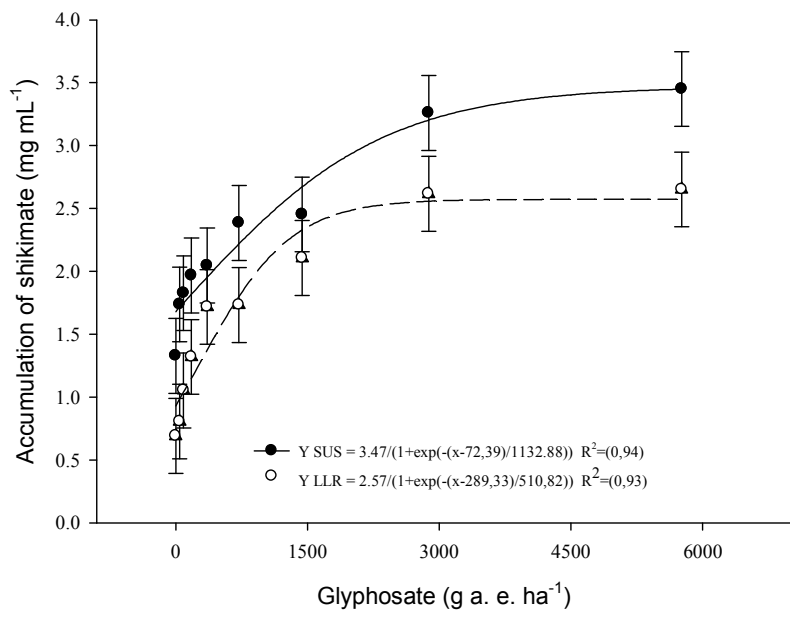

The points represent the average values of the repetitions and the bars represent their average confidence intervals.

Figure 2 - Accumulation of shikimate $\left(\mathrm{mg} \mathrm{mL}^{-1}\right)$ in biotypes of goosegrass (Eleusine indica) susceptible (SUS) and with low-level resistance (LLR) due to the application of different doses of herbicide glyphosate, assessed 24 hours after the treatment (HAT). 
and LLR biotypes (Table 5), respectively, representing approximately $400 \%$ increase comparing to the susceptible biotype. At the maximum glyphosate dose assessed, $5,760 \mathrm{~g}$ a.e. $\mathrm{ha}^{-1}$, the accumulation of shikimate was 3.47 and $2.57 \mathrm{mg} \mathrm{mL}^{-1}$ in the susceptible and LLR biotypes, respectively. The biotype of Echinochloa colona, resistant to glyphosate, presented approximately $400 \%$ increase in the value of $I_{50}$ when comparing to the susceptible biotype (Alarcón-Reverte et al., 2013). As for the goosegrass biotype resistant to glyphosate in Mississippi, they presented values of $\mathrm{I}_{50}$ up to $800 \%$ higher than for the susceptible biotype (Molin et al., 2013). It should be noted that the biotype in the study presents LLR, and this is controlled when using the maximum dose recorded $\left(2,160 \mathrm{~g}\right.$ a.e. $\left.\mathrm{ha}^{-1}\right)$ in the desiccation for direct seeding (Vargas et al., 2013).

Based on the absence of overlapping of the confidence interval (CI) of the susceptible biotype in relation to the CI of the LLR biotype, the RF value of 4.01 was established in the assessment carried out at 24 HAT with glyphosate (Table 5). A study developed with goosegrass biotypes has demonstrated that biotypes considered resistant had $R F$ values of 4.9, 6.2 and 8, calculated based on the accumulation of shikimate (Molin et al., 2013).

Biotypes of Lolium rigidum resistant to glyphosate have not shown increased shikimate concentrations after the treatment with the herbicide (Yanniccari et al., 2012). Similarly, biotypes of Digitaria insularis resistant to glyphosate have shown no shikimate accumulation after the treatment with the equivalent to 720 g a.e. ha ${ }^{-1}$ of glyphosate, having, among others, low translocation of the herbicide as a resistance mechanism (Carvalho et al., 2012).

The response difference in the shikimate accumulation in biotypes resistant to glyphosate is related to the mechanism that gives resistance and the change in the site of action avoids the shikimate accumulation in resistant biotypes (Molin et al., 2013). Considering the results, it is concluded that the goosegrass LLR biotype has no glyphosate metabolism via application of malathion as an inhibitor of the cyt-P450 complex. Moreover, it is also concluded that there are no anatomical evidences to determine the differential absorption of glyphosate by the goosegrass LLR biotype. However, there is evidence of lower absorption and translocation of glyphosate in this biotype by the lower stomatal density and smaller phloem diameter. It is also concluded that the goosegrass susceptible biotype has higher accumulation of shikimate compared to the biotype with LLR, leading to infer that the resistance mechanism is related to the insensitivity of the target enzyme to the herbicide. However, further studies should be conducted to confirm the goosegrass LLR mechanism, evaluating the mutation in the gene responsible for coding the enzyme (target site resistance), the translocation of the herbicide, the overexpression of the target enzyme or the increased EPSPs enzyme activity.

\section{ACKNOWLEDGMENT}

To FAPERGS [Fundação de Amparo à Pesquisa do Estado do Rio Grande do Sul (Foundation for Research Support of the Brazilian state of Rio Grande do Sul)] and CNPq [Conselho Nacional de Desenvolvimento Científico e Tecnológico (National Counsel of Technological and Scientific Development)] for the financial support (Notice 22/2010 - REPENSA).

\section{REFERENCES}

Alarcón-Reverte R. et al. Resistance to glyphosate in junglerice (Echinochloa colona) from California. Weed Sci. 2013;61:48-54. 
Benedetti J.G.R. et al. Período anterior a interferência de plantas daninhas em soja transgênica. Sci Agr. 2009;10:289-95.

Carvalho L.B. et al. Pool of resistance mechanisms to glyphosate in Digitaria insularis. J Agric Food Chem. 2012;60:615-22.

Cutter E.G. Anatomia vegetal. Parte I. Células e tecidos. 2ª ed. São Paulo: Roca, 1986. 304 p.

Dinelli G. et al. Physiological and molecular bases of glyphosate resistance in Conyza bonariensis biotypes from Spain. Weed Res. 2008;48:257-65.

Ferreira E.A. et al. Estudos anatômicos de folhas de espécies de plantas daninhas de grande ocorrência no Brasil. IV - Amarathus deflexus, Amarathus spinosus, Alternanthera tenella e Euphorbia heterophylla. Planta Daninha. 2003;21:261-3.

Ferreira E.A. et al. Translocação do glyphosate em biótipos de azevém (Lolium multiflorum). Planta Daninha. 2006;24:365-70.

Galvan J. et al. Anatomia foliar de Lolium multiflorum sensível e resistente ao glyphosate. Planta Daninha. 2012;30:407-13.

Gazziero D.L.P. et al. Critérios para relatos oficiais estatísticos de biótipos de plantas daninhas resistentes a herbicidas. In: Agostinetto D., Vargas L., editores. Resistência de plantas daninhas a herbicidas no Brasil. Pelotas: UFPel, 2014. p.91-101.

Ge X. et al. Rapid vacuolar sequestration: the horseweed glyphosate resistance mechanism. Pest Manage Sci. 2010;66:345-8.

Gonzáles-Torralva F. et al. First evidence for a target site mutation in the EPSPS 2 gene in glyphosate-resistant Sumatran fleabane from citrus orchards. Agron Sustain Develop. 2014;34:553-60.

Heap I. International survey of herbicide resistant weeds. [acessado em: 17 de junho de 2016] Disponível em: <http:// www.weedscience.org/Summary/Species.aspx?WeedID $=81>$..

Hess F.D., Falk R.H. Herbicide deposition on leaf surfaces. Weed Sci. 1990;38:280-8.

Huangfu C. et al. Morphological disparities in the epidermal and anatomical features of the leaf among wild Brassica juncea populations. Weed Biol Manage. 2009;9:234-42.

Malpassi R.N. Herbicide effects on cuticle ultrastructure in Eleusine indica and Portulaca oleracea. Biocell. 2006;30:51-6.

Menendez, J. et al. Resistance to chlortoluron in a downy brome (Bromus tectorum) biotype. Weed Sci. 2006;54:237-45.

Molin W.T. et al. Glyphosate resistant goosegrass from Mississippi. Agronomy. 2013;3:474-87.

Nol N. et al. Shikimate leaf disc assay for early detection of glyphosate resistance in Conyza canadensis and relative transcript levels of EPSPS and ABC transporter genes. Weed Res. 2012;52:233-41.

Norsworthy J.K. et al. Confirmation and control of glyphosate-resistant giant ragweed (Ambrosia trifida) in Tennessee. Weed Technol. 2010;24:64-70.

Perez-Jones A. et al. Investigating the mechanisms of glyphosate resistance in Lolium multiflorum. Planta. 2007;226:395-404.

Powles S.B., Yu Q. Evolution in action: plants resistant to herbicides. Ann Rev Plant Biol. 2010;61:317-47.

Riar D.S. et al. Resistance of Echinochloa crus-galli populations to Acetolactate Synthase-Inhibiting herbicides. Inter J Agron. $2012 ; 2012: 1-8$.

Roso A.C., Vidal R.A. A modified phosphate-carrier protein theory is proposed as a non-target site mechanism for glyphosate resistance in weeds. Planta Daninha. 2010;28:1175-85.

Roman E.S. et al. Como funcionam os herbicidas: da biologia à aplicação. Passo Fundo: Berthier; 2007. 160 p.

Seefeldt S.S. et al. Log-logistic analysis of herbicide dose-response relationships. Weed Technol. 1995;9:218-227.

Sociedade Brasileira da Ciência das Plantas Daninhas - SBCPD. Procedimentos para instalação, avaliação e análise de experimentos com herbicidas. Londrina: 1995. 42 p. 
Ulguim A.R. et al. Manejo de capim-pé-de-galinha em lavouras de soja transgênica resistente ao glifosato. Pesq Agropec Bras. 2013;48:17-24.

Vangessel M.J. et al. Influence of glyphosate-resistant horseweed (Conyza Canadensis) growth stage on response to glyphosate applications. Weed Technol. 2009;23:49-53.

Vargas L. et al. Low level resistance of goosegrass (Eleusine indica) to glyphosate in Rio Grande do Sul-Brazil. Planta Daninha. 2013;31:677-86.

Vidal R.A. et al. Resistência de Eleusine indica aos inibidores de ACCase. Planta Daninha. 2006;24:163-71.

Yanniccari M. et al. Glyphosate resistance in perennial ryegrass (Lolium perenne L.) from Argentina. Crop Protec. 2012;32:12-6.

Yu Q. et al. Distinct non-target site mechanisms endow resistance to glyphosate, ACCase and ALS-inhibiting herbicides in multiple herbicide-resistant Lolium rigidum. Planta. 2009;230:713-23.

Yu Q. et al. Evolution of a double amino acid substitution in the 5-enolpyruvylshikimate-3-phosphate synthase in Eleusine indica conferring high-level glyphosate resistance. Plant Physiol. 2015;167:1440-7.

Zhu J. et al. Transcriptome response to glyphosate in sensitive and resistant soybean. J Agric Food Chem. 2008;56:6355-63. 